\title{
ANALISIS PROFIL KEMAMPUAN LITERASI SAINS SISWA SMP/MTs DI KABUPATEN PATI
}

\author{
Nurul Hidayah ${ }^{1}$, Ani Rusilowati ${ }^{2}$, Masturi ${ }^{3}$ \\ ${ }^{1,2,3}$ Prodi Pendidikan Fisika, Program Pascasarjana, Universitas Negeri Semarang
}

\begin{abstract}
The aims of this study to describe the science literacy profile of junior high school students in science learning. The research sample is the students of class IX junior high school in Pati. The research using this descriptive method, data were collected by using science literacy test questions, questionnaires, and interview formats. The results showed that the average achievement of student science literacy as a whole was $28,31 \%$. Ability to explain scientific phenomena of $28.64 \%$, students 'ability in evaluating and designing scientific investigation of $24.48 \%$ and students' ability in interpreting data and scientific evidence of $31.81 \%$. This shows that the mean percentage of science literacy on three science literacy capacities measured shows $<50 \%$. The low one of the literacy skills of science will affect the ability of other science literacy. Based on the questionnaire analysis used in the research reveals factors that affect the ability of science literacy students include interest in science, learning motivation, teacher strategy in learning, and school facilities.
\end{abstract}

Keywords: Analysis, Scientific Literacy Skills, Physics

\begin{abstract}
Abstrak
Tujuan dari penelitian ini adalah mendeskripsikan profil literasi sains siswa SMP. Sampel dari penelitian adalah siswa kelas IX SMP di Pati. Penelitian ini menggunakan metode deskriptif, data dikumpulkan dengan tes literasi sains, kuisioner, dan wawancara. Hasil penelitian menunjukkan bahwa rerata pencapaian literasi sains siswa secara keseluruhan adalah $28,31 \%$. Kemampuan untuk menjelaskan fenomena saintifik sebesar $28.64 \%$, kemampuan siswa mengevaluasi dan mendesain investigasi saintifik sebesar $24.48 \%$ dan kemampuan siswa melakukan interpretasi data dan eksperimen saintifik adalah $31.81 \%$. Hal ini menunjukkan bahwa rerata persentase literasi sains dari ketiga kemampuan tersebut menunjukkan $<50 \%$. Rendahnya kemampuan literasi sains berdampak terhadap kemampuan literasi sains yang lain. Berdasarkan analisis kuisioner yang digunakan dalam penelitian menunjukkan faktor yang menyebakan kemampuan literasi sains siswa yaitu ketertarikan pada sains, motivasi belajar, strategi guru dalam pembelajaran, dan fasilitas sekolah.
\end{abstract}

Keywords: Analisis, Kemampuan Literasi Saintifik, Fisika 


\section{PENDAHULUAN}

Literasi sains telah menjadi istilah yang digunakan secara luas sebagai karakteristik penting yang harus dimiliki oleh setiap warga negara dalam masyarakat modern. Okada (2013) menyatakan bahwa literasi sains tidak hanya diinterpretasikan sebagai kemampuan untuk membaca dan memahami sains tetapi juga kemampuan untuk memahami dan menerapkan prinsip sains dalam kehidupan. Hal ini bersesuaian dengan pernyataan Holbrook dan Rannikmae (2009) bahwa terdapat dua pandangan utama mengenai literasi sains, yaitu pandangan yang memberikan penekanan pada peranan utama pengetahuan sains dan pandangan yang mengedepankan manfaat sains pada kehidupan manusia dalam masyarakat.

Masih rendahnya tingkat literasi sains siswa menjadi salah satu permasalahan pendidikan di Indonesia. Hal ini didukung oleh data pencapaian literasi sains siswa Indonesia dalam asesmen literasi sains PISA.Selama empat tahun terakhir mengikuti assesmen literasi sains PISA tahun 2006, 2009, 2012, dan 2015, rata-rata pencapaian skor literasi sains siswa masih dalam rentang skor 382 - 403. Hal ini berarti bahwa kemampuan literasi sains siswa Indonesia masih rendah dibandingkan rata-rata kemampuan literasi sains siswa dari negara-negara peserta yang lainnya (Toharudin, dkk., 2011). Kondisi ini mendorong perlunya dilakukan upaya-upaya perbaikan terhadap pembelajaran sains di sekolah secara bertahap dan berkesinambungan (Asyhari, 2015).

Checkley (2010) menyatakan bahwa Fisika merupakan mata pelajaran yang penting dan patut dikuasai oleh siswa pada era kemajuan teknologi dan informasi saat ini. Dengan demikian penguasaan terhadap sains Fisika merupakan sesuatu yang tidak dapat dihindari oleh siswa dalam proses pendidikan dan pembelajaran (Ukoh, 2012).

Hasil observasi yang dilakukan terhadap beberapa sekolah di Kabupaten Pati menunjukkan hasil bahwa pembelajaran IPA yang dilaksanakan belum mengarah pada pengembangan literasi sains siswa. Dalam menyampaikan pembelajaran guru tidak memulai dengan menghadirkan fenomena-fenomena ilmiah, sehingga siswa terlihat kesulitan dalam mengaitkan konsep yang dipelajari dengan fenomena yang terjadi di kehidupan sehari-hari.Pada beberapa materi tertentu, guru sudah menggunakan kegiatan eksperimen namun kebermaknaan eksperimen tersebut masih dipertanyakan karena eksperimen dilakukan hanya untuk konfirmasi konsep.Siswa melakukan kegiatan 
penyelidikan dengan mengikuti prosedur yang telah ditetapkan.Selain itu, soal-soal yang diberikan masih terbatas pada soal-soal yang menuntut ingatan dan pemahaman konsep.Sains pada dasarnya mencari hubungan kausal antara gejala-gejala alam yang diamati, oleh karena itu proses pembelajaran sains seharusnya mengembangkan kemampuan bernalar dan berpikir sistematis selain kemampuan deklaratif yang selama ini dikembangkan (Maturradiyah, 2015). Penilaian otentik dengan menggunakan beragam instrumen sangat potensial digunakan untuk mengukur literasi sains siswa (Chiu \& Chang, 2005).

Terdapat beberapa faktor yang mempengaruhi rendahnya literasi sains siswa. Faktor-faktor tersebut antara lain adalah pertama, rendahnya kemampuan literasi sains siswa dapat disebabkan kebiasaan pembelajaran IPA yang masih bersifat konvensional serta mengabaikan pentingnya kemampuan membaca dan menulis sains sebagai kompetensi yang harus dimiliki siswa (Norris \& Pillips, 2003). Kedua, kemampuan siswa dalam menginterpretasikan grafik/tabel yang disajikan dalam soal (Rahayu, 2015). Siswa terbiasa hanya mengisi tabel yang telah disediakan oleh guru, sehingga kemampuan siswa dalam menginterpretasikan grafik/tabel juga terbatas. Ketiga, siswa tidak terbiasa mengerjakan soal tes literasi sains (Sariati, 2013). Keempat, siswa tidak memahami konsep dasar yang diajarkan oleh guru (Rusilowati, 2016).

Kondisi di atas mengindikasikan bahwa perlu dilakukan upaya-upaya perbaikan terhadap pembelajaran sains di sekolah khususnya pada bidang fisika. Upaya perbaikan kualitas pembelajaran di tingkat sekolah perlu didukung informasi yang akurat tentang sejauh mana capaian literasi sains siswa. Oleh sebab itu perlu dilakukan analisis terhadap kemampuan literasi sains siswa SMP dan MTs di Kabupaten Pati.

\section{METODE PENELITIAN}

Metode penelitian yang digunakan dalam penelitian ini adalah kualitatif. Metode kualitatif digunakan karena metode ini lebih mudah memberi gambaran riil tentang keadaan yang terjadi di lapangan. Sampel penelitian adalah siswa SMP/ MTs kelas IX di Kabupaten Pati. Sampel ditentukan secara cluster sampling menurut letak geografis sekolah. SMP/MTs dan jumlah sampel yang terpilih sebagai sampel dapat dilihat pada Tabel.1 
Tabel 1. Sampel Penelitian

\begin{tabular}{lll}
\hline & Sekolah & Jumlah Sampel \\
\hline Kategori I & SMP N 1 Juwana & 30 \\
Kategori II & SMP N 5 Pati & 30 \\
Kategori III & SMP N 2 Winong & 27 \\
Kategori IV & MTs Tarbiyatus Syiban & 28 \\
\hline
\end{tabular}

Kemampuan literasi sains siswa dapat diukur dengan menganalisis penguasaan siswa dalam setiap kategori kemampuan literasi sains (Rusilowati, 2016). Untuk keperluan penelitian, instrumen yang digunakan dalam penelitian ini adalah instrumen tes literasi sains berupa tes uraian dan angket. Data yang diperoleh dalam penelitian ini berupa data hasil tes literasi sains, dan hasil pengisian angket. Setelah data terkumpul dilakukan reduksi data yang bertujuan untuk memfokuskan pada hal-hal yang akan diteliti yaitu menganalisis jawaban siswa yang telah dipilih dalam penelitian (Sugiyono. 2005).

\section{HASIL DAN PEMBAHASAN}

Hasil analisis data menunjukkan variasi tingkat kemampuan literasi sains siswa pada masing-masing sekolah. Rerata capaian literasi sains domain keterampilan dapat dilihat pada Gambar 4.1

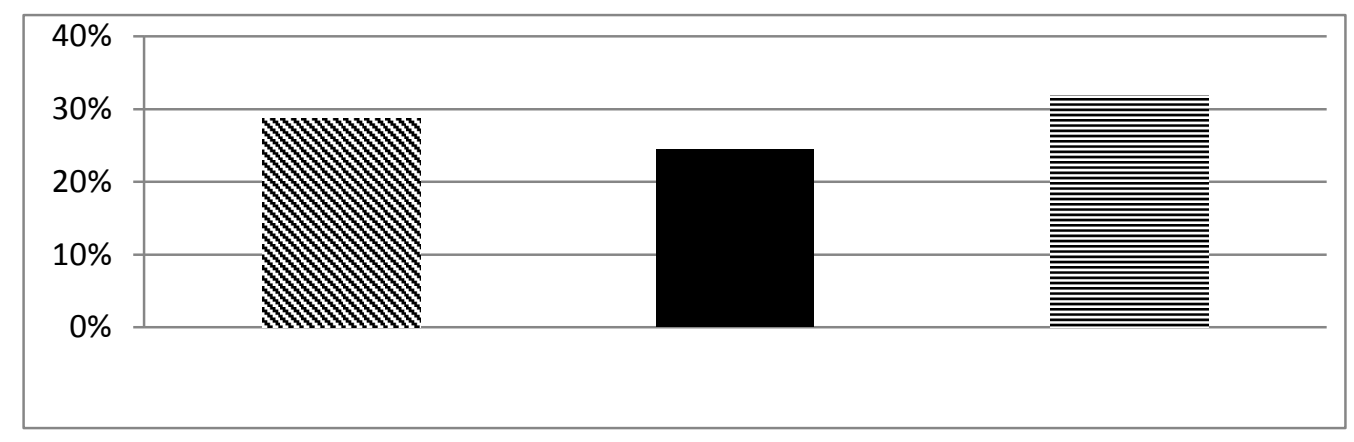

Gambar 4.1. Rerata Capaian Literasi Sains Domain Keterampilan

Keterangan:

: Kemampuan Menjelaskan Fenomena Ilmiah

: Kemampuan Mengevaluasi dan Merancang Penyelidikan Ilmiah

: Kemampuan Menafsirkan Data dan Bukti Ilmiah 
Berdasarkan data hasil penelitian yang diperoleh dari tes tertulis yang dikerjakan oleh sampel objek penelitian didapatkan persentase secara global sebagai berikut: (1) kemampuan siswa dalam menjelaskan fenomena ilmiah, persentase rata-ratanya hanya mencapai 28,64 \%, (2) kemampuan siswa dalam mengevaluasi dan merancang penyelidikan ilmiah $24,48 \%$ dan (3) kemampuan siswa dalam menafsirkan data dan bukti ilmiah 31,81\%. Grafik 4.1 menunjukkan bahwa rata-rata persentase literasi sains siswa pada 3 kemampuan literasi sains yang diukur menunjukkan $<50 \%$. Hal ini relevan dengan hasil penelitian Ibrahim \& Aspar (2006) bahwa ada keterkaitan antara pengetahuan sains dan aplikasi sains. Dengan demikian rendahnya salah satu kemampuan literasi sains akan berpengaruh terhadap kemampuan literasi. Literasi sains merupakan kombinasi antara sikap, keterampilan, dan pengetahuan siswa yang perlu dikembangkan dalam hal inkuiri, pemecahan masalah, pembuat keputusan, bahkan menjadi pembelajar seumur hidup dan mempertahankan rasa ingin tahu tentang dunia di sekitar mereka (Kermin, 2015).

Dari hasil keseluruhan data tersebut, dapat kita kelompokkan menjadi empat kategori sekolah yang menjadi sampel penelitian. Hasil persentase kemampuan literasi sains domain kompetensi pada setiap sekolah dapat dilihat pada Gambar 4.2

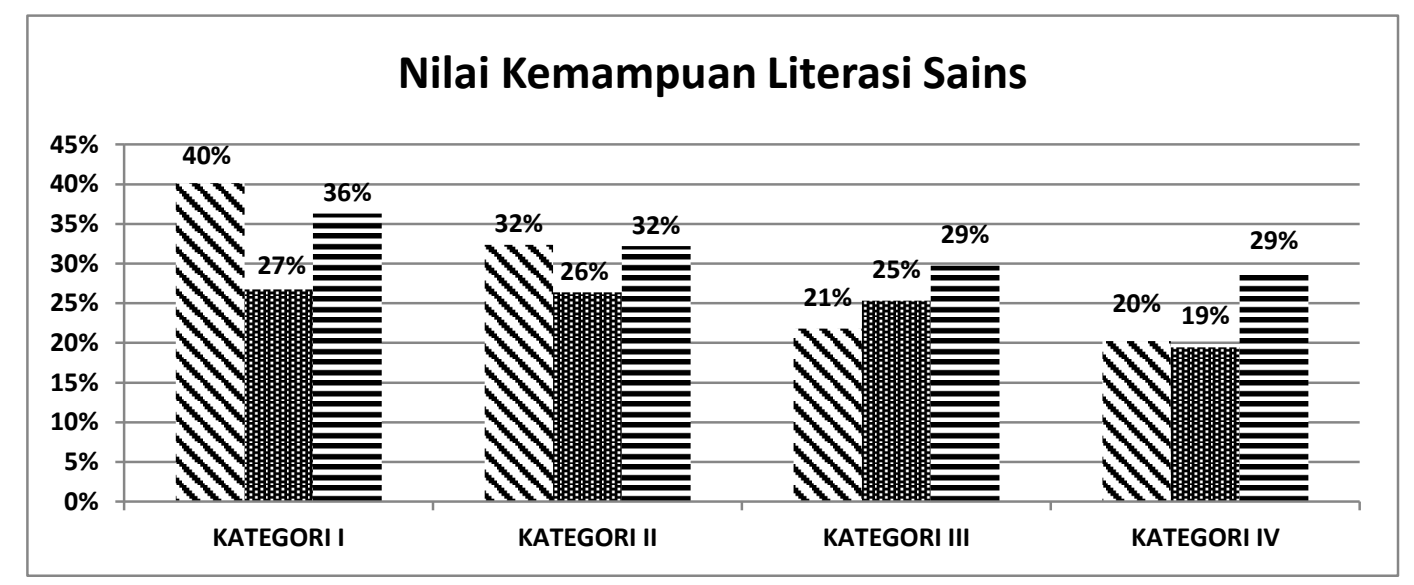

Gambar 4.2 Nilai Rata-rata Domain Kompetensi Literasi Sains Setiap Sekolah

Keterangan:

Kategori I : SMPN 1 Juwana

Kategori II : SMPN 5 Pati

Kategori III : SMPN 2 Winong

Kategori IV : MTs Tarbiyatus Sibyan 


\section{$\mathbb{N}:$ Kemampuan Menjelaskan Fenomena Ilmiah \\ IIIIIII : Kemampuan Mengevaluasi dan Merancang Penyelidikan Ilmiah \\ : Kemampuan Menafsirkan Data dan Bukti Ilmiah}

Sekolah yang memiliki nilai tertinggi pada semua kemampuan literasi sains adalah sekolah kategori I. Sekolah kategori IV memiliki nilai rata-rata terendah pada tiap aspek kemampuan literasi sains. Pada kenyataannya, sains adalah salah satu mata pelajaran utama di sebagian besar sistem pendidikan dunia. Alokasi waktu untuk pengajaran sains mencerminkan pentingnya ilmu pengetahuan dari sudut pandang sehari-hari dan situasi kerja (Sothayapetch, 2013). Ada beberapa faktor yang menyebabkan tiap sekolah memperoleh nilai rata-rata tes literasi sains yang berbedabeda. Fakta di lapangan saat penelitian berlangsung, sekolah kategori I lebih serius mengerjakan tes dan mempersiapkan dengan baik mulai dari belajar kisi-kisi yang diberikan oleh guru sampai selesai pelaksanaan tes terlaksana sangat kondusif dan serius. Sekolah kategori IV mengerjakan asal-asalan dengan kondisi kelas yang tidak kondusif tanpa ada persiapan belajar sebelumnya. Penegasan dari guru tiap sekolah juga mempengaruhi tingkat keseriusan siswa dalam mengerjakan dan mempersiapkan diri untuk tes.

Ditinjau dari data yang diperoleh, kemampuan literasi sains siswa yang berbeda tersebut dimungkinkan terjadi. Hal ini disebabkan oleh beberapa faktor yang saling berperan dalam mempengaruhi kemampuan literasi sains siswa. Berdasarkan hasil wawancara dengan siswa kelompok tinggi di sekolah kategori I ditemukan fakta bahwa orang tua mereka memiliki latar belakang pendidikan tinggi. Meskipun pendidikan orang tua tidak bergantung pada pengajaran sains, ia mempunyai pengaruh yang lebih besar pada literasi sains daripada pengaruh aktivitas pengajaran. Lingkungan keluarga yang berpendidikan mempunyai pengaruh positif terhadap kinerja akademik siswa. Program dukungan keluarga dapat mendorong siswa belajar lebih rajin di rumah maupun sekolah. Berdasarkan pengamatan proses pembelajaran di dalam kelas pada sekolah kategori I, pada tahapan pendahuluan guru mengkondisikan siswa, menyampaikan tujuan pembelajaran dan memotivasi siswa. Tahapan ini penting dilakukan sebelum memasuki pembelajaran. Sebagaimana yang diungkapkan oleh Hofstein \& Lunetta (2003) bahwa dengan menyampaikan tujuan pembelajaran siswa akan mengetahui tujuan dari kegiatan yang akan dilakukan sehingga siswa mempunyai 
gambaran kegiatan dan semakin termotivasi untuk mengikuti pembelajaran.

Hasil pengamatan proses pembelajaran pada sekolah kategori IV sangat berbeda dengan sekolah pada kategori I. Pada sekolah kategori IV ini, tahapan pendahuluan tidak terlaksana dengan baik. Guru memasuki ruang kelas dan kemudian menjelaskan mengenai topik tertentu. Hal ini yang menyebabkan siswa hanya berperan sebagai penerima informasi tanpa ada aktivitas aktif yang terlihat dari siswa. Sehingga mengakibatkan kemampuan siswa dalam menjelaskan fenomena ilmiah rendah. Tampaknya pendidikan di Indonesia lebih menekankan pada abstract conceptualization dan kurang mengembangkan active experimentation, padahal seharusnya keduanya seimbang secara proporsional (Yuliyanti, 2014). Hal ini senada dengan hasil penelitian Odja \& Payu (2014) bahwa kemampuan literasi sains siswa hanya dalam kategori dimana siswa setuju atau tidak setuju terhadap suatu pernyataan, tetapi siswa tidak mampu untuk memberikan penjelasan secara ilmiah. Faktor-faktor tersebut menunjukkan bahwa proses pembelajaran di sekolah sangat berpengaruh terhadap pencapaian literasi sains siswa. Selain itu, guru mempunyai peran penting dalam mengembangkan literasi sains siswa dalam proses pembelajaran.

Menurut OECD (2013) semua kompetensi literasi sains menuntut pengetahuan. Berdasarkan pernyataan tersebut maka sesuai dengan pengembangan soal literasi sains pada framework PISA 2015, tes literasi sains yang dikembangkan dalam penelitian ini adalah multidimensional, artinya selain digunakan untuk mengukur kompetensi, butir soal yang sama sekaligus juga dapat mengukur pengetahuan siswa. Distribusi soal dalam instrumen untuk setiap domain pengetahuan terlihat pada Gambar 4.3.

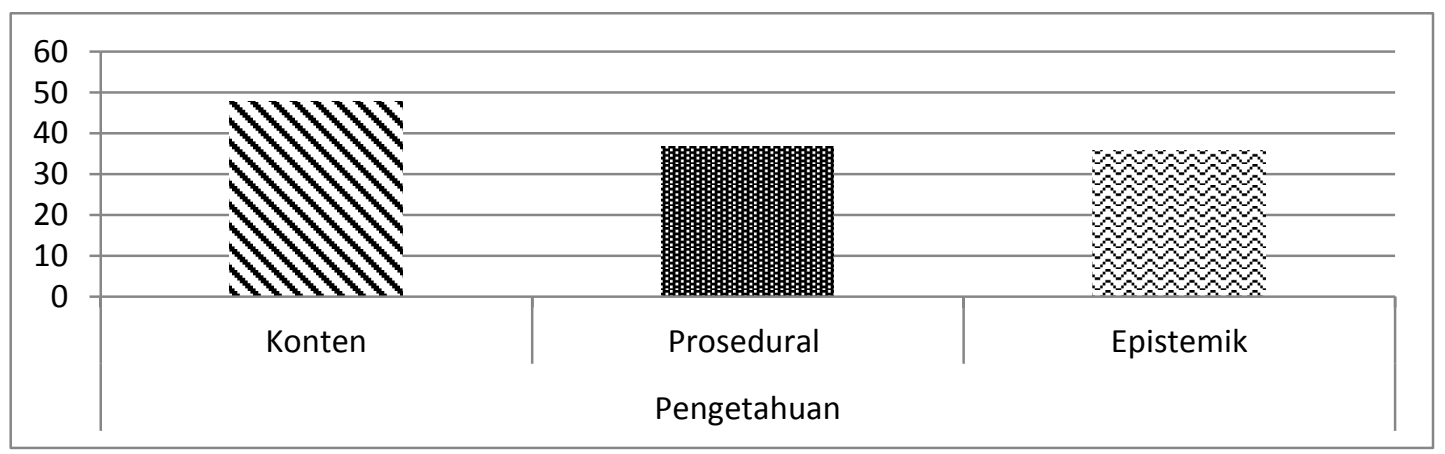

Gambar 4.3 Pencapaian Siswa Pada Setiap Domain Pengetahuan 
Berdasarkan analisis angket yang digunakan dalam penelitian mengungkap faktorfaktor yang mempengaruhi kemampuan literasi sains siswa meliputi: (1) minat terhadap sains, (2) motivasi belajar, (3) strategi guru dalam pembelajaran, dan (4) fasilitas sekolah, diperoleh hasil yang cukup beragam dari faktor-faktor tersebut dan juga dari tiap kategori sekolah.

Adapun hasil dari persentase faktor yang mempengaruhi kemampuan literasi sains siswa pada siswa SMP dan MTs di Kabupaten Pati dapat dilihat pada Gambar4.4

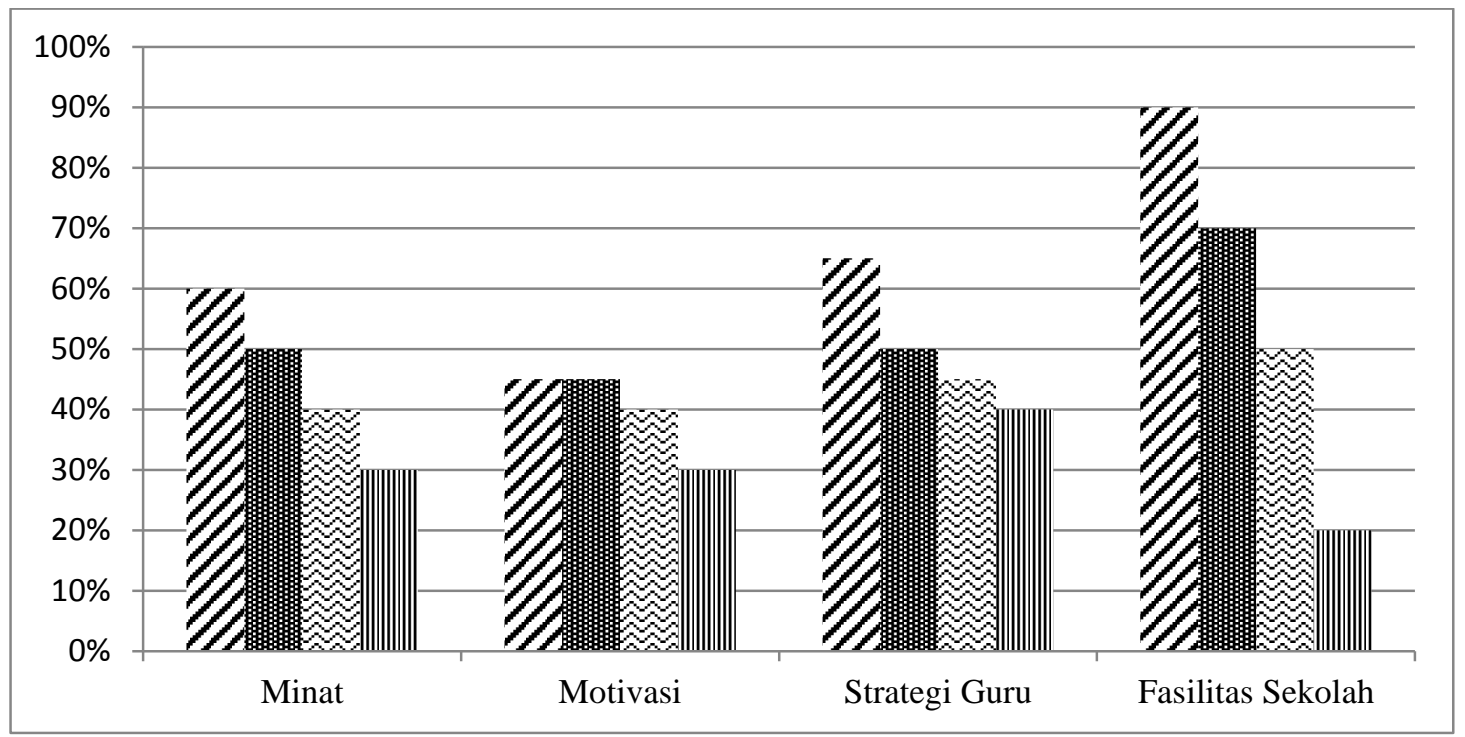

Gambar 4.4 Persentase Faktor yang Mempengaruhi Kemampuan Literasi Sains

Pada aspek minat belajar sekolah kategori I menunjukkan bahwa perolehan persentase sebesar 60,16\%, sekolah kategori II menunjukkan perolehan persentase sebesar 52,36\%, sekolah kategori III menunjukkan perolehan persentase sebesar 41,79 $\%$ dan sekolah kategori IV menunjukkan perolehan persentase sebesar 30,23\%. Selain itu, siswa kurang memperhatikan ketika pembelajaran berlangsung yang ditunjukkan seringnya siswa bercerita dengan temannya sendiri saat berlangsungnya pembelajaran Fisika di kelas.

Aspek yang kedua, motivasi belajar dalam penelitian ini dijabarkan menjadi beberapa indikator yang meliputi: (1) perhatian terhadap pembelajaran Fisika, (2) usaha untuk belajar fisika, (3) Aktivitas saat pembelajaran Fisika. Pada aspek motivasi diperoleh persentase $65,00 \%$, untuk sekolah kategori I sebesar 46,77\%, sekolah kategori II menunjukkan persentase sebesar 46,35\%, sekolah kategori III menunjukkan 
persentase sebesar 40,33\% dan sekolah kategori IV menunjukkan persentase sebesar 29,47\%. Berdasarkan pernyataan yang digunakan pada angket dapat diketahui bahwa jika ada suatu materi yang tidak dimengerti siswa saat pembelajaran Fisika, siswa tidak berusaha bertanya kepada guru atau siswa lain yang lebih paham. Hal ini didukung oleh penelitian Lukyto (2009) yang menunjukkan bahwa siswa tidak terlibat secara aktif saat proses pembelajaran, sehingga siswa cenderung pasif dalam pembelajaran. Seorang guru harus berupaya membangun motivasi dan partisipasi siswa dalam belajar sains, sehingga siswa mau berbuat dan belajar, dengan cara menciptakan situasi belajar sains yang komprehensif mengacu pada ide dan gagasan literasi sains (Yulin, 2015).

Aspek yang ketiga, strategi guru dalam melaksanakan pembelajaran. Aspek ini dijabarkan menjadi beberapa indikator yang meliputi: (1) penguasaan materi Fisika, (2) kejelasan menerangkan, (3) penggunaan metode belajar, dan (4) penggunaan alat peraga. Pada aspek ini diperoleh persentase untuk sekolah kategori I sebesar $65 \%$, sekolah kategori II sebesar 50\%, sekolah kategori III sebesar 45\%, dan sekolah kategori IV sebesar $40 \%$. Berdasarkan pernyataan yang digunakan pada angket dapat diketahui bahwa metode yang digunakan guru tidak bervariasi dan cenderung menggunakan metode ceramah. Selain itu, guru masih kurang dalam menggunakan laboratorium dalam kegiatan pembelajaran Fisika.Selanjutnya guru masih kurang dalam menggunakan alat peraga baik itu langsung maupun tidak langsung.

Aspek yang keempat adalah fasilitas sekolah. Aspek fasilitas sekolah merupakan faktor eksternal yang berasal dari sekolah. Aspek ini dijabarkan menjadi beberapa indikator meliputi: (1) fasilitas yang ada di sekolah, (2) kondisi dan letak gedung. Hal ini senada dengan penelitian dari Alam (2015) bahwa rendahnya aspek literasi sains disebabkan karena kurangnya fasilitas di sekolah untuk pelajaran yang melatih literasi sains.

\section{SIMPULAN}

Kemampuan literasi sains domain kompetensi siswa SMP/MTs di Kabupaten Pati meliputi (1) kemampuan siswa dalam menjelaskan fenomena ilmiah, persentase rataratanya hanya mencapai $28,64 \%$, (2) kemampuan siswa dalam mengevaluasi dan merancang penyelidikan ilmiah 24,48 \% dan (3) kemampuan siswa dalam menafsirkan data dan bukti ilmiah 31,81 \%.Profil literasi sains siswa berdasarkan aspek PISA masih 
dominan dalam penjelasan fenomena ilmiah, tidak jauh berbeda dengan profil kompetensi sains siswa berdasarkan aspek literasi sains yang masih dominan dalam aspek sains sebagai tubuh dari pengetahuan (Basam, 2017).

Berdasarkan analisis angket yang digunakan dalam penelitian mengungkap faktorfaktor yang mempengaruhi kemampuan literasi sains siswa meliputi: (1) minat terhadap sains, (2) motivasi belajar, (3) strategi guru dalam pembelajaran, dan (4) fasilitas sekolah, diperoleh hasil yang cukup beragam dari faktor-faktor tersebut dan juga dari tiap kategori sekolah. 


\section{DAFTAR PUSTAKA}

Alam, D. P., Utari, S., \& Karim, S. 2015. Rekonstruksi Rancangan Rencana Pelaksanaan Pembelajaran Sains Melalui Analisis Kesulitan Literasi Sains Peserta Didik SMP Kelas VII pada Topik Gerak Lurus. Prosiding. Simposium Nasional Inovasi dan Pembelajaran Sains 2015 (SNIP 2015). Universitas Pendidikan Indonesia 8 dan 9 Juni 2015

Asyhari, A. \& Hartati, R. 2015. Profil Peningkatan Kemampuan Literasi Sains Siswa Melalui Pembelajaran Saintifik. Jurnal Ilmiah Pendidikan Fisika AlBiruni.Vol 2:179-191

Basam, F., Rusilowati, A., \& Ridlo, S. 2017. Analysis of Science Literacy Learning with Scientific Inquiry Approach in Increasing Science Competence of Students. Journal of Primary Education. Vol 6 (3): 174-184

Checkley, D. 2010. High School Students' Perceptions of Physics, Faculty of Education. Lethbridge, Canada

Chiu, M. \& Chang, S. 2005. The Development of Authentic Assessment to Investigate Ninth Graders Scientific Literacy. International Journal of Science and Mathematics Education, Vol 3:117-140

Hofstein, A. \& Lunetta, V. N. 2003. The Laboratory in Science Education: Foundations for the Twenty-First Century. Science Education, 88(2):28 - 54.

Holbrook, J. \& Rannikmae, M. 2009.The Meaning of Scientific Literacy. International Journal of Environmental \& Science Education, 4 (3): 275-288.

Ibrahim, M.A. \& Aspar, N.H. 2006 Tahap Literasi Sains dalam Kalangan Pelajar Tingkatan Empat Sekolah Akhir Agam di Daerah Hilir Perak. Perak: UTM.

Kermin, J., dkk. 2015. Perspective on Science Literacy: A Comparative Study of United States and Kenya. Educational Research International. Vol 4 (2): 25-34

Lukyto, Tatas. 2009. Hubungan Antara Kemampuan Dasar Matematika Dan Kebiasaan Belajar Peserta Didik Dengan Prestasi Belajar Fisika Pada Bab Cahaya Peserta Didik SMP Negeri 3 Ponorogo. UNM: Malang

Maturradiyah, N. \& Rusilowati, A. 2015 Analisis Buku Ajar Fisika SMA Kelas XII di Kabupaten Pati Berdasarkan Muatan Literasi Sains. Unnes Physics Education Journal, 4 (1):17-20

Norris, S.P. \& Phillips, L. M. 2003. How Literacy in its Fundamental Sense in Central to Scientific Literacy.Science Education, 87:224-240. 
Odja, A.H. \& C.S. Payu. 2014. Analisis Kemampuan Awal Literasi Sains Siswa pada Konsep IPA. Prosiding Seminar Nasional Kimia.Surabaya: Universitas Negeri Surabaya

OECD. 2013. PISA 2015: Draft Science Framework. Paris: OECD.

Okada, Alexandra. 2013. Scientific Literacy in the Digital Age: Tools, Environments and Resources For Co-Inquiry. European Scientific Journal, 4:1857-7881

Rahayu, D. B. 2015. Profil literasi sains siswa SMP kelas VII pada tema efek rumah kaca. Tesis. Bandung: Sekolah Pascasarjana, Universitas Pendidikan Indonesia.

Rusilowati, A., dkk. 2016. "Developing an Instrument of Scientific Literacy Asessment on the Cycle Theme". International Journal of Enviromental \& Science Education, 11(12): 5718-5727.

Sariati, D. 2013. Analisis keterampilan proses pada penggunaan Hierarki Inkuiri dan dampaknya terhadap literasi sains siswa SMP. Tesis. Bandung: Sekolah Pascasarjana, Universitas Pendidikan Indonesia.

Sothayapetch, P., dkk. 2013. A Comparative Analysis of PISA Scientific Literacy Framework in Finnish and Thai Science Curricula. Science Education International. Vol 24: 78-97

Sugiyono. 2005. Memahami Penelitian Kualitatif. Jakarta: Alfabeta.

Toharudin, U., Hendrawati, S., \& Rustaman, A. 2011. Membangun literasi sains siswa. Bandung: Humaniora.

Ukoh, E.E. 2012. Effect of Interactive Invention Instructional Strategy on NCE Pre-Service Teacher's Achievement in Physics and Acquisition of Science Process Skills. Journal of Innovative Research in Managementand Humanities, 3 (1), $122-131$.

Yuliyanti, T.E. \& Rusilowati, A. 2014. Analisis Buku Ajar Fisika SMA Kelas XI Berdasarkan Muatan Literasi Sains di Kabupaten Tegal. Unnes Physics Education Journal. Vol 3 (2): 68-72

Yulin, T. \& Rusilowati, A. 2015. Pengembangan Buku Ajar IPA Terpadu Berorientasi Literasi Sains Materi Energi dan Suhu. Journal of Innovative Science Education. Vol 4 (2): 34-40 